JONARDON GANERI

\title{
OBJECTIVITY AND PROOF IN A CLASSICAL INDIAN THEORY \\ OF NUMBER
}

\section{MATHEMATICS AND THE PHILOSOPHICAL THEORY OF NUMBER}

The theory of number serves as a highly instructive example of the nature of rationality, theory-change and philosophical thinking in India. I will show how the processes of theory rejection and theory modification are driven by perceived explanatory failure rather than by discovery of foundational incoherence. I will argue too that the source of structure, order and pattern is seen to reside in the natural world, and not in any domain of abstract objects or in the empirically unconstrained working of a priori reflection. The discussion of number broaches fundamental questions about the nature of objectivity and the correspondence theory of meaning, and it explores the basic principles underlying the construction of a formal ontology. At the end, I will make some comparisons between Indian philosophers' theory of number and the Indian mathematicians' description of the epistemology of mathematics and the nature and function of mathematical proof.

The philosophical study of number in India specifically, the theory of the realist Nyāya-Vaiśeșika school, ${ }^{1}$ belongs with the analysis of the structure of empirical knowledge. This theory of number is an account of the semantics and epistemology of contingent numerical judgements, judgements whose subject matter concerns questions of numerical quantity. Such judgements are typically expressed by statements like 'there are two pots in this room' or 'there are nine planets in the solar system'. The study of number is therefore an enquiry into the role of number within empirical and scientific knowledge. Like much classical philosophy in India, the Nyāya-Vaiśeșika theory of number is broadly empiricist: facts about the numerical properties of objects do not differ in kind from facts about their colour, shape or extension. Number is part of the natural world. While these philosophers generally do not discuss explicitly the nature of mathematical truth, they implicitly favour an empiricist philosophy of

Synthese 129: 413-437, 2001.

(C) 2001 Kluwer Academic Publishers. Printed in the Netherlands. 
mathematics, according to which the laws of arithmetic are of the same kind as the laws of nature, differing only in the degree of generality they possess.

Numerals have three distinguishable grammatical roles. They function as adjectives in sentences like 'there are nine planets', as predicates in sentences like 'the planets are nine' and as substantives in sentences like 'nine is the square of three'. In keeping with their disinterest in mathematical truth, these authors do not much discuss the substantival use of the numerals, which is the use most relevant to arithmetic. Because the numerals are not treated as names of numbers, but rather as numerical predicates, there was no reason to introduce numbers into the ontology as objects; there is no tendency, for example, to analyse number set-theoretically. The adjectival and predicative role of the numerals, on the other hand, are analysed in depth. It is a result of modern semantic theory that the adjectival use of the numerals can be expressed in a first- order language with identity, and this result is partly anticipated by Bhāsarvajña. The dominant approach, however, was to treat numbers as properties of objects, exactly as colour adjectives stand for colour properties. A strict semantic realism among these philosophers led to the reification of anything which appears in thought or language. However, in their fascinating treatment of vagueness and the term 'many', the Nyāya-Vaiśeșika philosophers reach the limits of their semantic realism.

\section{NUMBER AS A PROPERTY OF OBJECTS}

\subsection{The 'number of qualities' problem}

Numbers are mentioned by Kanada (c. AD 100) in Vaiśsesikasūtra 1.1.9 as one member in a list of seventeen kinds of 'quality' (guna). The Vaiśeșika concept of a quality is a technical one. Qualities are distinguished, on the one hand, from substances and movements, and on the other, from universals and the so-called 'particularities' (viśesa). A quality is a nonrepeatable property-particular, a trope. The specific shade of grey a cloud has at a moment in time is in this sense a quality, something which is different from, and yet belonging to the same general type as, every other shade of grey. The Vaiśeșika qualities are defined further as properties of substances alone. An immediate corollary (VS 2.1.16) is that qualities do not themselves have qualities. The category of quality is not restricted, however, to monadic property-particulars; some qualities, for example contact and disjunction are relation-particulars. 
Vaiśesika theory assimilates numbers into the category of qualities. There is, in a given pair of objects, a specific quality of duality. This duality is different from the duality in any other pair, and yet all such dualities belong to the same universal kind twoness. As one is a number, every object possesses a unit- quality, distinct from but of the same kind as every other unit-quality. The theory is based on a reasonable intuition that when a number of objects are collected together, the number of objects in the collection is a fact about the objects over and above the facts about the individual objects. It is, however, highly problematic, as the Nyāya-Vaiśeșika authors were well aware. Following the terse discussion in VS 7.2.1-9, the difficulty most strongly emphasised is the problem of accounting for our apparent ability to speak of numbers of things other than substances:

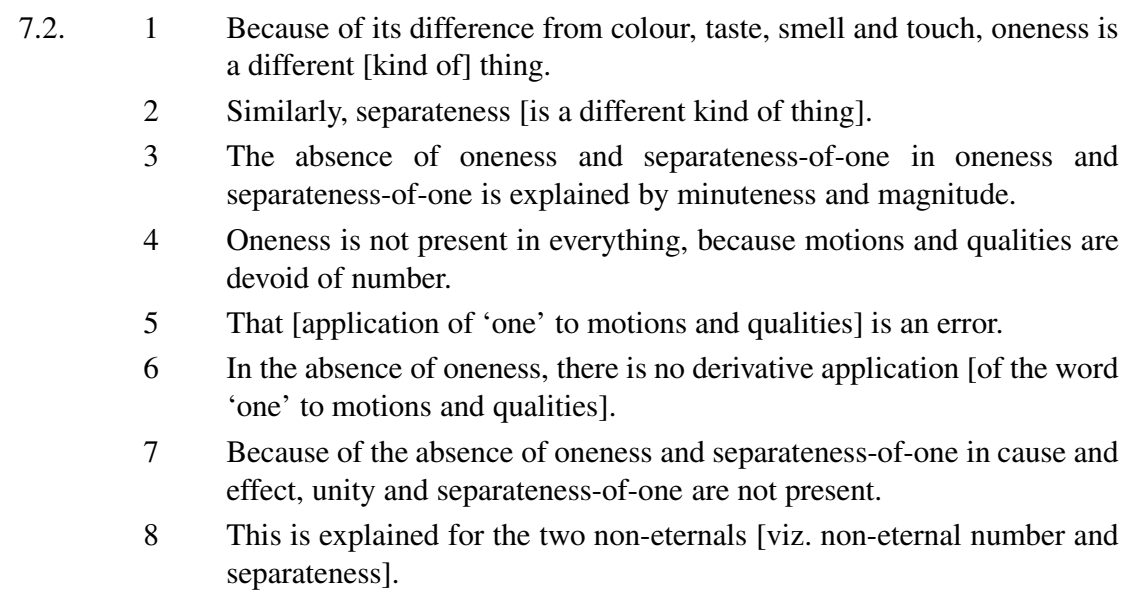

The principal objection rehearsed here is that individual substances each have the numerical quality of being one, and yet, since qualities do not inhere in qualities or motions, individual qualities and motions cannot be said to be numerically one. We might call this the 'number of qualities' problem.

The Vaiśesikasūtra solution to the problem is disarmingly simple. It consists in denying that it is literally and properly correct to speak of a number of qualities. It would be an error to do so. The Vaiśeșikasūtra explanation for the use of the term 'one' to objects other than substances is that it is a derivative use, a metonymic extension of the term beyond the domain of its proper application. VS 7.2.6 is to be understood in this context as pointing out that if the term 'one' were not properly applicable somewhere, i.e., to substances, then it could not be used metonymically either. According to the standard analysis of derivative meaning (laksana $\bar{a}$ ), a term may refer derivatively to objects that are in some way related to the 
literal reference of the term (see Raja 1963: 231-233, Ganeri 1999: 91-94). One may say 'The platform is shouting', meaning that the people on the platform are shouting. The point of 7.2.6 is then that without a base use of the numeral 'one' to substances, there could be no metonymic application of the term to other categories of thing. ${ }^{2}$

At face value, this attempt to solve the problem has little to recommend it. There is nothing about the use of numerals in statements about quality and motion to distinguish it from the use in application to substances. ${ }^{3}$ The expression 'two' has precisely the same meaning in 'There are two pots on the ground' as in 'There are two shades of blue in this painting' or 'There are two movements in that dance-step'. Later writers took the idea to be that such statements are indirect ways of talking about the number of substances. Bearing in mind that qualities are nonrepeatable properties, it follows that there are exactly as many shades of blue as there are blue things. We might hope, then, to paraphrase a statement about the number of blue qualities as a statement about the number of blue substances. The idea is that the phrase 'two (shades of) blue' does not attribute a quality (two) to a quality (shade of blue), but attributes both qualities to a substance. It is paraphrased as 'two blue (substances)'. The relation between numbers and qualities is not one of inherence but rather one of 'co-inherence in a single substratum'.

\subsection{The problem of self-inherence}

This is, perhaps, a solution to the 'number of qualities' problem. However, as later authors were well-aware, the problem is only a special case of some more general difficulty. For Śankara Miśra (c. 1430), the real problem is one of self-inherence. The trouble is with talking about the number of numbers, and it presents the same difficulty as talking about the movement of movements or the quality of qualities. He therefore explains VS 7.2.3 in the following way (1923:174):

[Objection:] Since one can say such things as 'oneness is one' or 'separateness is separate from colour and so on,' surely oneness is in oneness and separateness is in separateness. Because of this, it is said [7.2.3] that 'the absence of oneness and separateness-of-one in oneness and separateness-of-one is explained by minuteness and magnitude'. [The meaning is that ] just as minuteness and magnitude do not possess minuteness and magnitude, the application of which [characteristics] to them is derivative, so oneness and separateness do not possess oneness and separateness, the application of which to them is derivative. Two later sūtras, viz. "by motions, motions" [7.2.24], and "by qualities, qualities" [7.2.25] exhibit the same derivative meaning as this earlier one. The meaning is that just as motions do not possess motions and qualities do not possess qualities, so too oneness and separateness do not possess that [oneness and separateness]. 
Śankara Miśra's argument is that because nothing can inhere in itself, apparently acceptable talk of self-inherence must be non-literally construed. In particular, when we say that there is one number one, we are not really saying that the number one inheres in itself, any more that when we say that minuteness is minute, we are saying that minuteness inheres in itself. The point does not apply to numbers other than one, since we would not say that there are two number twos, even if we want to say that there is one number one. So for Śankara Miśra, the non-literal use of numerals is restricted solely to the use of 'one' to itself.

Śankara Miśra is right to be worried about the idea of self-inherence. It is a straightforward matter to modify Russell's paradox and show that the property of non-self-inherence is incoherent. For let $\mathrm{R}$ be the property of being a non-self-inherent property. Is R self-inherent or not? If it selfinherent, then (by the definition of R) it is a non-self-inherent property which is a contradiction. If it is not self-inherent, then (by the definition of R) it is not a non-self-inherent property - again contradictory. Russell's solution in his Theory of Types was to block the paradox by ruling as insignificant the application of a property to itself, so that the incoherent property cannot be formulated (cf. Sainsbury 1979: 315, 1995: 111). It is a little surprising that none of the Nyāya-Vaiśeșika authors discovered the paradox. There is, however, some hint of it in Gangeśa's account of 'nonpervasive' location (see Matilal 1975: 455-7). As has recently been shown, the celebrated grammarian Bhartrhari hit upon a paradox of a rather similar type, when he argued that the denotation relation is undenotable, on the grounds that no relation can have itself as a relatum (H. \& R. Herzberger 1981; Houben 1996).

\subsection{The problem of cross-categoricity}

The self-inherence problem is not a grave difficulty for the general theory that numbers are qualities, for most numbers are not self-inherent, even if it forces us to regard the claim that there is one number one as having only non-literal significance. More serious is the problem that numbers are cross-categorial, that entities in any category can be enumerated. This is seen by Raghunātha (see below) as a fatal flaw in the doctrine. If we can speak about the number of things in any category, then in what category do we place numbers themselves? We may note here in passing that in contemporary discussions of number, the theory that numbers are properties of objects is considered refuted by the simple observation that, in a statement like 'there are two people in the room', no one person is said to be two (cf. Sainsbury 1991: 159). This observation, however, refutes only the thesis that numbers are unary properties; it leaves open the possibility that they 
are many-place relations. It is for the same reason that the statement 'the people in the room are friends' does not imply that each person is a friend. I discuss this further below.

\section{NUMBER AS A RELATION OF NON-IDENTITY}

Bhāsarvajña (c. 950) is a radical Naiyāyika who rejects the classical Vaiśesika theory that numbers are qualities. His discussion of number is very astute and insightful, and contains some important innovations. His theory is that number adjectives do not stand for qualities of substances, but for relations of identity and difference (1968:159):

Identity and difference depend on sameness and distinctness in colour and so on, and so are not considered to be qualities. Further, it is a tautology to say "the one is identical" or "the many are different."

Bhāsarvajña's idea is simplest to see in the case of the predicative use of numerals. The statement ' $a$ and $b$ are one' is, he claims, synonymous with ' $a=b$ '. To say that Hesperus and Phosphorus are one is just to assert the identity 'Hesperus $=$ Phosphorus'. On the other hand, the statement ' $a$ and $b$ are two' asserts that $a \neq b$. The adjectival use of numerals admits of a similar analysis. Indeed, it is now standard to formalise sentences of the form 'there are $n F \mathrm{~s}$ ' by means of non-identity. The analysis varies, depending on whether we read the sentence as asserting that there are at least $n F \mathrm{~s}$ or as asserting that there are exactly $n F \mathrm{~s}$. Thus, 'there are at least $n F \mathrm{~s}^{\prime}$ is paraphrased by (see Sainsbury 1991: 160):

$$
\begin{aligned}
& \left(\exists x_{1}\right)\left(\exists x_{2}\right) \ldots\left(\exists x_{n}\right)\left(F x_{1} \& F x_{2} \& F x_{n} \& x_{1} \neq x_{2} \& x_{2} \neq\right. \\
& \left.x_{3} \& x_{1} \neq x_{3} \& \ldots \& x_{n-1} \neq x_{n}\right) .
\end{aligned}
$$

The problem of the 'number of qualities' presents no particular difficulty for this account. For to say that there are two shades of blue in the painting is to assert that the two shades are different from each other. As long as we can refer to and quantify over qualities, the analysis is the same as before. The analysis of statements involving 'one' as identity statements is the source of some unclarity. Udayana (c. 1000) objects to the account on the grounds that identity is something unique to each thing, but we can say 'one pot', 'one cloth', and so on. Since the identity of the pot is not the same as the identity of the cloth, it cannot be the meaning of the adjective 'one' here (Udayana 1956: 442; cf. Potter 1977: 597). The objection seems to be that if ' $a$ is one' means ' $a=a$ ', then the predicate '.. is one' means $' \ldots=a^{\prime}$, and ' $b$ is one' then comes to mean ' $b=a$ ' rather than ' $b=b$ '. 
This objection has some force if Bhāsarvajña's claim is that 'one' means identity in the sense of the individuating essence of a thing. But we need not read him this way. It is not after all very clear what we are doing when we say that something is one, but Bhāsarvajña's proposal is that we are not attributing a property to the object, but asserting, trivially, that it is identical to itself.

It is interesting to note that Bhāsarvajña's analysis is echoed, very much later, in Gadādhara's comments on the meaning of the word 'one'. Gadādhara (c. 1650) is discussing the adjectival use of the term, and he states that the meaning of 'one $F$ ' is: an $F$ as qualified by being-alone, where 'being alone' means 'not being the counterpositive of a difference resident in something of the same kind' (Gadādhara 1929: 189). In other words, 'one $F$ ' is to be analysed as saying of something which is $F$ that no $F$ is different to it. If this is paraphrased in a first-order language as

$$
F x \& \neg(\exists y)(F y \& y \neq x)
$$

then it is formally equivalent to a Russellian uniqueness clause:

$$
F x \&(\forall y)(F y \rightarrow y=x)
$$

This idea, that as used adjectivally 'one' expresses uniqueness, seems to be in the spirit of Bhāsarvajña's claim that it expresses the identity of a thing. In any case, it is clear that, for Gadādhara, 'one' has a role similar to that of the definite article.

After presenting his radical analysis, Bhāsarvajña goes on to claim for it a much greater degree of generality than possessed by the old account (1968: 159):

Now the application of 'twoness' to qualities etc. is unproblematic. Moreover, even its use in arithmetic, as when one says "a hundred and a half a hundred by six hundred" goes through. So it is said that one is the initial integer, two is that [one] together with another identical, three is [those] two together with another identical, four is those [three] together with another identical, and so on. The convention for the grounds for the use of 'twoness' etc., established by the treatises on arithmetic, is explicable [in this way].

Bhāsarvajña reveals here a clear awareness that the integers can be defined recursively, and, unusually for the Nyāya-Vaiśeșika authors, displays some familiarity with the mathematical literature. He says that one is the first whole number, two is one together with another identical, three is two together with another identical, and so on. The Sanskrit term for integer is 'abhinna', which means 'undivided' or 'whole', as well as 'identical', and Bhāsarvajña plays on the ambiguity in order to switch from the adjectival to the substantival use of numerals. 


\section{NUMBER AND COLLECTION}

The anomalous status of numbers in the traditional Vaisesika system is perceived very clearly by Raghunātha Śiromani (c. 1510). In another radical departure, he declares numbers to belong to a new category altogether (1957: 86-7, Potter's translation, slightly emended):

Number (is) a separate category, not a (kind of) quality, for (we make) the judgment (that there is) possession of that (namely, number) in qualities, etc. And this (judgment we make that qualities have number is) not an erroneous one, for (there is) no (other) judgement (we make which contradicts (it). If (you argue) that judgments of this kind (occur when there) is inherence of two qualifiers in one individual (substance), (I say) no, for inherence and inherence-of-two-qualifiers-in-one-substratum (are) two (quite) different (connectors), from which (one) cannot derive the homogenous idea of possession. And just as the judgement of oneness in potness, etc., (is to be explained by the opponent) through inherenceof-two-qualifiers-in-one-substratum, so (there ought to be) a judgment of twoness in colourness, etc., (explainable) through inherence-of-two-qualifiers-in-one-substratum, and that (is) not possible.

Raghunātha puts his finger in exactly the right place: the is-the-numberof relation is not reducible to the relation of inherence or any relation constructed out of it. The fact that each quality is unique to the substance it inheres in means that there is a one-to-one correspondence between substances and qualities. So we might hope to paraphrase talk of the number of qualities with talk of the number of substances. But this will not solve the cross-categorial problem, since we can also count universals.

On the other hand, merely to say that numbers belong in a category of their own does not yet tell us very much about them. Raghunātha's main contribution to the Nyāya-Vaiśeșika theory of number lies in his account of the relation between numbers and things numbered and its distinction from the inherence relation. He observes that while inherence is a distributive relation, the number-thing relation has to be collective. The distinction occurs in the context of sentences with plural subjects, for example, 'the trees are old'. An attributive relation is distributive if it relates the attribute to every subject: if the trees are old, then each individual tree is old. A relation is collective if it relates the attribute to the subjects collectively but not individually. Thus, 'the trees constitute a forest' does not imply that each tree constitutes a forest. Number attributions are collective. If one says that there are two pots here, one does not imply that each pot is two. Inherence, however, is a distributive relation, and so cannot be the relation of attribution for numbers. This relation is called the 'circumtaining' relation (paryāpti) by Raghunātha (p. 38):

the 'circumtaining' relation, whose existence is indicated by constructions such as "This is one pot" and "These are two", is a special kind of self-linking relation. 
His commentator Jagadīśa explains:

It might be thought that the circumtaining relation is [in fact] nothing but inherence .... So Raghunātha states that circumtaining [is a special kind of self-linking relation].... In a sentence like "This is one pot", circumtaining relates the property pot-hood by delimiting it as a property which resides in only one pot, but in a sentence like "These are two pots", circumtaining relates the property twoness by delimiting it as a property which resides in both pots. Otherwise, it would follow that there is no difference between saying "These are two" and "Each one possesses twoness".

Thus, the number two is related by the circumtaining relation to the two pots jointly, but to neither individually. If it were the case that collective relations have to be analysed as relations to classes, and not to the members of classes, then Raghunātha's idea would resemble to some degree Frege's definition of numbers as properties or classes of classes (cf. Ingalls 1951: 77; Shaw 1982). This is, however, premature, for we are not forced to analyse all collective relations as relations to classes (cf. Mohanty 1992: 246; Ganeri 1996). Indeed, the idea that numbers relate to objects collectively is quite consistent with Bhāsarvajña's idea that number statements are statements of the mutual distinctness of a plurality. The significance of Raghunātha's innovation is that the domain of numbers is seen now to relate to the world of objects in a way very different from that of the domain of universals and qualities. Numbers thereby acquire an distinctive ontological status, although there is no reason to suppose that Raghunātha takes them to be abstract or Platonic objects.

\section{PRAŚASTAPADA'S 'EIGHT MOMENTS' THEORY}

Praśastapāda (c. 530) supplements the Vaiśesikasūtra account of number with a detailed description of the ontogenesis of numbers, and of the psychological process by which they come to be cognised. The entire process is supposed to take eight moments of time (1923: 48-50):

When [1] the eye of the cogniser contacts with a pair of substances of a similar or a dissimilar type, a cognition arises [2] of the generic oneness which inheres in those [qualities] which inhere in the objects of contact, and then [3] a single awareness arises of the two unitqualities from the cognition of the relation between them and the generic oneness. Next [4] twoness begins to form from the two unit-qualities in their substrata, in dependence of that [single awareness]. But then [three things happen] at a single time [5]: a cognition of the universal twoness arises in this; the start of the decline of the combinative cognition (apekșäbuddhi) due to that cognition of the universal twoness; and the beginning of the emergence of a cognition of the duality-quality from the cognition of the relation between it and the generic twoness. And now, [three more things happen] at a single time [6]: due to the destruction of the combinative cognition, the duality-quality begins to decline; the cognition of the duality-quality causes the destruction of the cognition of the universal 
twoness; and there begins to emerge a cognition of the two substances, in the form '[there are] two substances' from the duality-quality and its relation to the cognition. Following this, [four things happen] at a single time [7]: the [full] arising of the cognition of the two substances in the form '[there are] two substances;' the destruction of twoness; the beginning of the decline of the cognition of the duality-quality; and the beginning of the emergence of a dispositional memory trace from the cognition of the two substances. Following this [8], [there is] the destruction of the cognition of the duality-quality from the cognition of the two substances, and the [full] dispositional memory state also from the cognition of the two substances.

This intricate description of the process is distilled by later writers into the following sequence of eight events (cf. Udayana 1956: 449, Śankara Miśra 1923:177):

(1) Sensory connection with the two objects.

(2) Awareness of the general property oneness.

(3) Combinative cognition.

(4) Production of twoness in the objects.

(5) Awareness of the general property twoness.

(6) Awareness of a duality-quality.

(7) Knowledge of the two substances as qualified by such a duality.

(8) Dispositional memory trace.

Praśastapāda's theory of the production of number and numerical knowledge is as follows. One first perceives two separate objects. On perceiving an object, one can become aware of the sorts of qualities it possesses. Technically, this type of awareness is called samyukta-samaveta-samaveta, awareness of what inheres in what inheres in the object directly seen. In this case, what one becomes aware of is the universal property oneness, a property which inheres in every unit-quality (property-particular), and so in the particular unit-qualities which inhere in the two perceived objects. The third step is a mental act of counting or enumeration, a 'combinative cognition'. The thinker collects the two objects into a single awareness, judging '(here is) one and (here is) one'. The mental counting up of the objects produces in those objects a new feature, the property of being two. Although produced by the cogniser's counting, and depending for its continued existence on the continuing existence of that event, the number is an objective property of the objects themselves. Once the number two has come into existence, it is possible for the cogniser to become aware of it. He becomes aware, first of all, of the universal property twoness which inheres in all duality-qualities, then of the particular duality-quality which inheres in the two perceived objects, and finally of the two objects as 
qualified by that particular duality-quality. This episodic knowledge-event gives way to a dispositional memory trace, which preserves the knowledge for the cogniser after the episodic knowledge-event has faded away.

A detailed examination of the psycho-dynamics of this account would be beside the point here. I will make a brief comment before turning to examine the important role attributed to the 'combinative cognition' or mental act of counting in the theory, and to its epistemology of number. The account depends on the Vaiśeșika doctrine that mental events have a life cycle of three moments. Created in the first moment, they develop into full-blown and causally efficacious events at the second moment, and then decline to their final destruction at the third. This leads to a difficulty in the eight-moments theory, for the number two in the objects, created at moment (4) will have ceased to exist by the time the cogniser becomes aware of it at moment (7). The Nyāya-Vaiśesika authors expend considerable energy on this rather sophistical puzzle. Potter (1977: 290) accurately observes that Praśastapāda's account tries to reconcile the theory with the doctrine that 'in order for one stage in a process to destroy the previous one that previous one must be capable of destruction'. Older theories apparently ran into a problem here, for the knowledge that the objects are two, which arises at moment (7), ought to but cannot destroy the number two, since that is already destroyed at moment (6). Praśastapāda's rather straightforward solution to the problem is to give the combinative cognition a life-span of four, rather than three, moments (cf. Faddegon 1918: 201).

\section{OBJECTIVITY IN THE THEORY OF NUMBER}

The doctrine that numbers are created by mental acts of counting is important but difficult. Potter regards the doctrine as 'a very dangerous admission' for a school that 'wishes to maintain a surefooted realism about the external world' (1977: 120). Among the Nyāya-Vaiśesiikas, Śrīdhara (c. $990)$ is most aware of the danger, and he reasons as follows (1977: 27-5):

This [combinative] cognition produces the twoness of the two objects which are the substrata, from the two unit-qualities which [each] depend on [the] universal oneness. The two substrata are inherent causes, the two unit-qualities are non-inherent causes, and the cognition of both is another causal factor .... The thesis that an object can be produced by a cognition is not an unworldly one, for the production of pleasure etc. from [cognitions] is seen [to be similar]. Nor is it right to say that there is a disanalogy [between numbers and pleasures] in that the production of an external object in such a way is not seen, for there is no distinction here between the two cases in the manifestation of the correlation [between cognition and production of object]. 
[Objection:] Although it has been shown that the causal foundation (ālambana) of the two qualities is what makes manifest the twoness, it is not the case that the cognition is its immediate antecedent cause. [Reply:] No, [if that were so then there would be] no regulation. If twoness were not produced by the cognition, then other people could cognise it, as with colours and so forth, because there would be no regulating causal factor. When produced by the cognition, however, this regularity arises: that which is produced by a person's cognition is ascertainable by him alone. The demonstration runs as follows -

(1) Twoness is produced by cognition,

(2) Because it is restricted to being thought of by a single cogniser.

(3) That which is restricted to being thought of by a single cogniser is produced by cognition; as, for example, a pleasure.

(4) Twoness is restricted to being thought of by a single cogniser.

(5) Therefore, it too is produced by cognition.

This is a very interesting passage. A number is an objective entity, even though it is both private (capable of being cognised by at most a single person) and also mind-created. The inference from privacy to being mindcreated is relatively unproblematic - it is hard to imagine how something which can only be cognised by a single person can be entirely mindindependent. But how does this give any support to the claim that numbers are objective? The analogy with pleasures and pains is apt, for the NyāyaVaiśesika entertain the curious theory that pleasures and pains are distinct both from their (mental) causes as well as from the perception of them (cf. Matilal 1986: 295-308). Pleasures and pains are also private to individuals, but, unlike numbers, they reside in the soul of the person and not in the outside world.

In saying that numbers have mental acts of counting as their causes, the Nyāya-Vaiśesika give voice to an intuition that there is an element of arbitrariness or a 'strain of subjectivity' (Matilal 1987: 19) in the numerical description of the world. Faddegon suggests that the arbitrariness lies in choosing a 'standard of counting, measuring, weighing' (1918: 206-7). What is certainly true is that the question 'How many things are there here?' has no determinate answer until we specify the sort of thing to be counted. As Frege said (1950, §22), 'while I am not able, simply be thinking of it differently, to alter the colour or hardness of a thing in the slightest, I am able to think of the Iliad either as one poem, or as 24 books, or as some large number of verses'. Yet the Nyāya-Vaiśesika do not seem to have the sortal dependency of counting in mind, when they say that numbers are produced in objects by mental acts of counting. For Praśastapāda explicitly said that the two things can be of similar or dissimilar kinds. Their point seems rather to be that the mental act is one of collecting together a number 
of objects, thereby making a particular group salient to the cogniser. From all the objects in the surroundings, the cogniser picks out in his mental act a selected subset. Looking at a garden full of trees, one might think 'these four trees are tall'. What makes it true that the subject in such a thought is a group of four trees, when there are many more trees around, is that those objects have been selected mentally by the cogniser. In other words, counting up the objects produces the number because it produces the group to which the number belongs. This in no way detracts from the objectivity of the number of objects being thought about, nor does it make the truth-value of the thought depend on anything other than the state of those objects.

Mental acts of counting and processes of selective attention seem to have a place only in judgements with demonstrative plural subjects. If one asks how many planets are there in the solar system, on the other hand, the number is fixed in advance of any counting up. In many cases, it is more natural to say that the number of things falling under a description is discovered and not created. The Nyāya-Vaiśeșika broach this problem with their account in the course of their discussion of indefinite pluralities, to which we shall turn. Before doing so, we may note another argument that Srīdhara has for the existence of numbers as external entities (1977: 270 ). It is that if numbers did not exist, then nothing would regulate our cognition of them:

if the forms [cognitions] of 'one', 'two' etc. were not compliant with external objects, they would not appear according to a condition of occurring from time to time. So number too is to be admitted, because there is no difference between the arising of both [cognitions of number and cognitions of other external things].

It is central to the concept of objectivity that external objects are thought of as capable of being perceived and of existing unperceived. A familiar neo-Kantian thought is that in order to make sense of the idea that one can perceive what can also exist unperceived, one must think of perception as having certain spatio-temporal 'enabling conditions', such that in order to perceive something one must be appropriately located - both spatially and temporally - with respect to it. ${ }^{4}$ One can then make sense of the fact that a perceivable object is not actually perceived by thinking that the enabling conditions for its perception are not satisfied. Śrīdhara's argument is similar: if numbers were not objective, then what we perceive would not be accountable to what there is to be perceived in our surroundings. Even though numbers have mental causes in the Nyāya-Vaiśeșika theory, the perception of a number is a distinct mental event with external 'enabling conditions'. 


\section{THE EPISTEMOLOGY OF NUMBER}

The first four steps in the 'eight moments' theory describe the origin of numbers greater than one as properties of a group of objects collected together by a mental act of counting. The second four steps describe the origin of our knowledge of those properties, once they have come into being. According to Vaiśesikasūtra 4.1.12-13, numbers are themselves perceptible when they reside in perceptible substances. In seeing a group of objects, we see also their properties, one of which is their number. The claim that we come to know of the number of objects perceptually is a little surprising, for one might have thought that it would be more natural to think of the act of counting itself as our means of coming to know how many objects there are. We have already seen, however, that it is crucial to Vaiśeșika realism to maintain a sharp distinction between the creative act of counting and the epistemology of numerical knowledge. Presumably when the collected objects are not perceptible, then the act of counting them is our primary epistemological access to their number.

Mathematical knowledge, as distinct from empirical knowledge of the number of things, is considered by western philosophers of mathematics to have a distinctive epistemological status. It is thought to be possible to know a priori, without recourse to any empirical enquiry, that for example $17 \times 27=459$. Interestingly, the Nyāya-Vaiśeșika did consider the hypothesis that mathematical truths are known by a special means, in the course of their discussion of the source of knowledge called 'inclusion' (sambhava). Inclusion is said to have been recognised as an independent source of knowledge by the Paurānikas. Vātsyāyana defines it as 'the cognition of the existence of one thing from the cognition of the existence of another thing never absent from the first' (1985: 574). He cites, as an example, coming to know of an ădhaka from a drona. Ạ̣haka and drona are both measures of grain, the former being one quarter of the latter. So the point is that one is in a position to know that one has a quantity $x$ of grain if one knows that one has a quantity of grain that includes $x$. Later writers give an example more relevant to our present purposes: the inference that there are a hundred of a certain thing because there are a thousand. We must take 'there are a hundred' to mean 'there are at least a hundred' and not 'there are exactly a hundred'. However, although they mention 'inclusion,' the Nyāya authors fail to recognise in it any distinctive epistemological features. They reduce it to the standard pattern of quasiinductive inference, in which one infers that something is $F$ because it is $G$, on the basis of one's knowledge that $F$ never occurs without $G$. Knowledge of the invariable concomitance between $F$ and $G$ is, however, taken 
to be derived from a search for counter-examples, cases where $F$ is present without $G$. As long as one can find no such counter-example, one has a good reason to believe that the properties are concomitant. The inference that there are a hundred because there are a thousand, on the other hand, is based on the inclusion of a hundred in a thousand, something which one can come to know without searching for counter-examples or performing any empirical enquiry. This example shows how the scientific empiricism of the Nyāya-Vaiśeșika authors deterred them, rightly or wrongly, from accepting the existence of a priori mathematical truth.

\section{THE MEANING OF 'MANY'}

An interesting and revealing discussion arose with respect to the meaning of sentences like 'There are many trees in the forest' or 'the army is composed of many soldiers'. In such statements, the adjective 'many' has, formally, a role quite like a numerical adjective. Śrîdhara is said indeed to argue that 'many' is itself a number, distinct from any number in the cardinal series. As Śanjkara Miśra (1923: 179) reports him:

'Since in the case of a forest or an army, there is no definite combinatory cognition [i.e. counting up of the number of trees or men], a mere manyness comes into being, but not the number a hundred or a thousand' - this is the view of the teacher Śrīdhara. ${ }^{5}$

If numbers are created by mental acts of counting, then the uncounted army or forest has no definite number of men or trees. The perceiver merely surveys the entirety, and judges 'there are many men' or 'there are many trees'. Srīidhara's view, it seems, is that in such a case an 'indefinite' act of counting produces in the objects the 'indefinite' number, many. That Śīdhara is forced into such a move indicates the presence of a deep faultline in the Nyāya-Vaiśeșika theory. The problem arises whenever one has a clearly delineated but uncounted collection of objects. The collection might, as in these cases, be a perceptible aggregate, or it might be picked out under a description, for instance 'planets in the solar system'. There seems in such cases to be an inconsistency between the common-sense intuition that the collection has some definite if unknown number, and the Nyāya-Vaiśeșika thesis that number is the result of a mental act of counting up the objects in the collection.

Udayana ridicules Śrīdhara's attempt to solve the puzzle by substituting a definite if unknown number with the known but indefinite number 'many'. He says (1956: 458):

Perhaps [as Śrıdhara says,] twoness is produced by a pure combinative cognition, threeness by a [combinative] cognition of a oneness with a twoness, fourness by a [combinative] 
cognition of a oneness with a threeness, etc. How about the army and the forest? It might be thought that there is here no [combinative] cognition of a oneness with some definite number, and moreover that no definite number such as a thousand comes into being. But still a mere 'manyness' comes into being without a specific universal [numerical property] from a combinative cognition, because it can have as its foundation an indefinite [number of] onenesses.

This [theory of Śrīdhara] is false. One could not then have a doubt [about the number of things] without there being a specific number of [things qualified by] pothood or [things] delicately distinguished, nor could there be such statements as 'the large army is larger' at the time of becoming aware of the addition of another group of men.

Śankkara Miśra summarises Udayana's argument: “ "No doubt could arise as to whether [the army] has a hundred or a thousand parts, nor could one judge 'the large army is larger'; so this is not right' - this is the view of the teacher Udayana" (1923:179). Udayana insists on the validity of common-sense: a doubt about the number of men in the army can arise only if one thinks of it as having a definite but unknown number. Still more devastating is his objection that if many is a number, we could not compare one group of many with another, or judge one group to be larger than another - for both would have the same number, many.

There is, however, a way to make sense of the idea of a definite but unknown number, if we clearly distinguish between the ontogenesis of numbers and their epistemology. In a normal case, the mental act of counting which produces the number will also manifest that number to the cogniser. That is to say, the means by which one comes to know how many objects there are will be precisely that act of counting them which produces the number in them. This need not always be the case. It is conceivable that some definite number can be produced in the objects by an indefinite mental act of counting, an act which will not itself supply the cogniser with any knowledge of the number of things. A definite or precise mental act of counting is both the cause and the 'manifestor' of the number. An indefinite or imprecise mental counting is the cause but not the manifestor of a number (Udayana 1956: 459). There is room in the theory for a gap between the creation and the discovery of numbers.

The meaning of the term 'many' presents another puzzle. NyāyaVaiśeșika semantic theory is by and large realist or referential: the meaning of a word is the object for which it stands (see Ganeri 1999: 82-107). The word 'many' cannot however stand for the actual number in the army (a thousand, say), for the sentence 'there are many men in the army' does not mean that there are a thousand men in the army. So 'many' must denote, as Uddyotakara clearly states, the distinct number manyness (1985:211):

What does the phrase 'large army' mean? The phrase 'large army' designates those very elephants etc. which are the abode of number, when increasing with the addition of new 
groups of men. So when the elephants etc. are described as 'large', the word 'large' denotes the number manyness which is the cause of the increase.

Śankara Miśra grapples with the same problem (1923: 180):

Is manyness nothing but number [beginning with] three and ending at parārdha, ${ }^{6}$ or a number different from them? Not the first, since even in the case of an army and a forest, there must be a definite number such as a hundred or a thousand. Nor the second, since a manyness distinguished from three etc. is never observed. So [Udayana says that] manyness is indeed a number such as a hundred, produced by a combinative cognition which does not have as its foundation a definite [number of] units; but [the number] a hundred is not revealed there because its manifestor is absent.

We, on the other hand, say that manyness is indeed a number different from but colocated with three etc., and produced by the combinative cognition that produces the threeness etc. It is different, because there is a difference in prior absence. How else could one say 'There are many, but I do not know if there are precisely a hundred or a thousand'? If asked the question 'Shall I bring a hundred or a thousand mangoes?', one replies 'Bring some large amount - why do you want to know the exact number?' Three is due to a combinative cognition [of one] with two; four is due to a combinative cognition [of one] with three; and so on higher and higher and higher. When manyness arises without a combinative cognition, it does not depend on specific earlier numbers. In the case of the army or the forest, manyness alone comes into being and not any other number. So the above dilemma is one with false horns.

Śankara Miśra's point is that what 'many' denotes is neither a particular number in the cardinal series, nor the series in totality, but rather a property that co-exists with the definite number the objects possess. It is, perhaps, the property of being large in number. 'Many' is in fact a vague predicate, and it is easy to see how a version of the Sorites paradox can arise. For if there are many men in the army, and one is taken away, there are still many men in the army. Repeating the process, however, one would eventually reach the situation where there are just two men in the army, and two is not many. Uddyotakara does indeed link 'many' with processes of increase, but none of the Nyāya-Vaiśesika authors formulate the Sorites paradox in this form.

In the discussion of the semantics of 'many', the Nyāya-Vaiśeșika authors explore the limits of the attempt to treat numerals as predicates, or names of properties. Frege's remarkable insight (1950) was that numerals are not predicates but quantifier expressions. Statements like 'there are seven $F$ s', really belong in the same semantic category as 'there are no $F$ s' and 'there are some $F$ s'. If ' $/ F /$ ' stands for the cardinality of the extension of ' $F$ ', then the semantics for such sentences follow a uniform pattern:

'there are no $F \mathrm{~s}$ ' is true iff $/ F /=0$

'there are some $F \mathrm{~s}$ ' is true iff $/ F />0$ 
'there are at least seven $F \mathrm{~s}$ ' is true iff $/ F / \geq 7$.

'there are exactly seven $F \mathrm{~s}$ ' is true iff $/ F /=7$.

When the numerals are recognised to be quantifier expressions, "more than' no longer causes any special difficulty:

'there are more $F \mathrm{~s}$ than $G \mathrm{~s}$ ' is true iff $/ F />/ G /$.

The Nyāya-Vaiśeșika authors, like their medieval counterparts in the West, approached semantics with a name-bearer model of the meaning relation, and do not develop an theory of quantification adequate to the expression of such terms.

\section{THE THEORY OF NUMBER AND INDIAN CONCEPTS OF RATIONALITY AND PROOF}

Among the most important features of the Indian theory of number, we may select the following:

(1) No distinction is drawn between scientific-empirical and mathematical truth. Mathematical objects are thought of as properties of the natural world, not as abstract or Platonic entities. Mathematical knowledge (e.g., that $17 \times 27=459$ ), in so far as it is considered at all, is not taken to be different in kind from empirical knowledge about the number of things of a certain type.

(2) Numbers are regarded as created, not discovered. In spite of this, they are thought to be genuinely objective properties of the natural world. The world is not thought of as intrinsically numbered, but numbers are nevertheless the external correlates of thought. The mental act of counting that creates a number is usually but not necessarily our source of knowledge about the number.

(3) The theory of number developed by the philosophers is not based on any great awareness of the work of mathematicians, nor is its purpose to study the philosophical foundations of mathematics or scientific practice.

(4) Neither Russell's paradox nor the Sorites paradox is recognised, even though they could easily have been formulated in the terms of the discussion.

(5) Numbers are not reduced to sets. Indeed, sets are not introduced into the ontology. The ontology is intensional, in that among its basic constituents are properties and relations rather than sets. 
We can see, then, that the 'official' philosophers in India did not try to analyse the philosophical basis of mathematics, but were more interested in describing the semantics of contingent numerical statements and the epistemology of empirical numerical knowledge. They tackled some problems in their theory (the 'number of qualities' problem, the treatment of 'many') but did not uncover other paradoxes and inconsistencies in their conceptual framework. They sought for a definition of objectivity which did not make it rest on mind-independence, but allowed for the mind to have a causal role in the creation of objective entities.

The account of number affords an instructive insight into the mechanisms of theory-change and internal criticism in Indian philosophical thinking. We have examined two cases where the theory was modified under pressure from within: the rejection of the assimilation of number to the category of quality by Bhāsarvajña and Raghunātha, and the jossling between Śrīdhara, Udayana and Śankkara Miśra over of the correct account of the term 'many'. What drove the revision in the first case was a perceived explanatory failure in the older theory. The account of numbers as qualities did not seem able to explain their cross- categorial behaviour, nor to give a satisfactory explanation of the relation between numbers and the world of objects. The old theory failed because it supplied no explanation of a range of observed facts about the actual use of the concept of number, in particular that the concept is applicable to objects in any ontological category. In the case of 'many', a failure to explain the observed application of the concept is again what drives the theory-modification. The facts in need of adequate explanation here are (i) that one can judge that there are many things of a certain type without knowing how many, and (ii) that different 'manys' are commensuble and capable of being ordered. The process of rejection and revision in Indian philosophical theory is driven, then, by a perceived mismatch between the older theory of a concept and the actual use of that concept in a range of cases.

Such a process of theory-rejection might be juxtaposed with another, according to which one looks for inconsistency or incoherence in the basic concepts and postulates which form the foundation of the theory. When successful, this method typically results in the discovery of paradox and absurdity. It has been a familiar element in philosophical thinking in the west since the Greeks (Zeno, Eubulides), but was not without its promoters in India (Sañjaya, Nāgārjuna, Śrīharșa). Now both Russell's paradox and the version of the Sorites paradox involving 'many,' point to a difficulty with fundamental presupposition in the Nyāya-Vaiśeșika theory, that every intelligible condition has a determinate application (pravrtti-nimitta). While the condition 'being a substance' has a determin- 
ate application to substances, and 'being two' has a determinate application to groups of two, neither the condition 'being many' nor the condition 'being non-self-inherent' have determinate applications - one is vague, the other is self-contradictory. My present point is that if the Nyāya-Vaiśeșika authors did not discover these paradoxes it was because the search for such paradoxes is not what drove their philosophical practice. The underlying idea in their philosophical theorising is that a theory is rationally acceptable if, or to the extent that, it explains actual use - the greater the range of uses explained, the better the theory. Coherence was, of course, a constraint on the adequacy of a theory, but the idea of rational acceptability as foundational coherence was not the active principle behind the rejection or revision of philosophical theory.

The Nyāya-Vaiśeșika theory of number reveals another important aspect of philosophical theorising in India: the importance of empirical grounding. The general importance attached to empirical grounding is to be seen in the role of the 'example' in the Nyāya informal logic, and in the subordinate status accorded to 'hypothetical reasoning' (tarka) (Matilal 1986: 78-80, Mohanty 1992: 117-8). Matilal suggest that a priori reasoning is not admissible because '[p]urely a priori certainty is not an acceptable certainty in a properly empirical philosophy .... [W] [hen no empirical evidence is forthcoming, the reductio will lose its utility. In this way, I think, the pramanna theorists were well equipped to resist the attempts of the sceptic-dialecticians who generally used the reductios (prasanga) to refute any philosophical position' (ibid.). Purely a priori reasoning is $d e$ structive. The pure working of the mind can create what it likes and destroy what it likes without regulation. Regularity, order, structure - these come from the natural world. Constructive reason is reason grounded in empirical evidence. Even the theory of number, apparently an entirely a priori discipline, would be baseless and arbitrary unless empirically grounded. Numbers, therefore, have to be observable features of the natural world, and not as abstract Platonic objects, and counting does not create numbers in the abstract, but rather numbered collections of observable objects. What is rejected here is the idea that there could be order among mathematical objects unless those objects were part of the natural world.

The 'official' philosophers in India were not the only ones to raise and discuss philosophical problems. Matilal (1989) claims, for example, that while the philosophers or pramanna theorists offered no account of moral theory, their failure to do so was compensated by the moral theorising of the epic authors, the later narrators who retold the epic stories with new nuances, the writers on dharmaśāstra and their commentators. The same is true in mathematics. The mathematicians themselves did reflect 
on the nature of their own enquiry into mathematical truth. Bhāskarācārya II states that 'utpatti (mathematical demonstration) is the means (pramāna) of establishing truth in mathematics' (reported in Srinivas 1992: 45). Bhāskara's commentator Ganeśa Daivajña defines an utpatti as follows (see Srinivas ibid: 44):

Whatever be stated in the vyakta or avyakta branches of mathematics without utpatti will not be rendered free from error. It will not acquire any standing in an assembly of scholarly mathematicians. The utpatti is directly perceivable like a mirror in the hand. It is for this reason, as also for the elevation of the intellect, that I proceed to enunciate utpatti in its entirety.

The purposes of mathematical demonstration are thus: (i) to eliminate uncertainty, (ii) to convince an assembly of experts, (iii) to make the mathematical result transparent, and (iv) to improve the intellect or scholarship of the reader. What is important to note here is how different this description of mathematical demonstration is from the concept of mathematical proof in the west, namely formal deduction in an axiomatic system. According the Indian mathematicians, the goal of a mathematical demonstration is to bring the reader to the point where they really understand how and why theorem or rule is correct. A particularly nice example is Ganeśa's geometrical demonstration of Pythagoras' Theorem (a theorem that is already explicitly stated in the Kalpasūtras). It consists in the following diagram, along with an accompanying explanation:

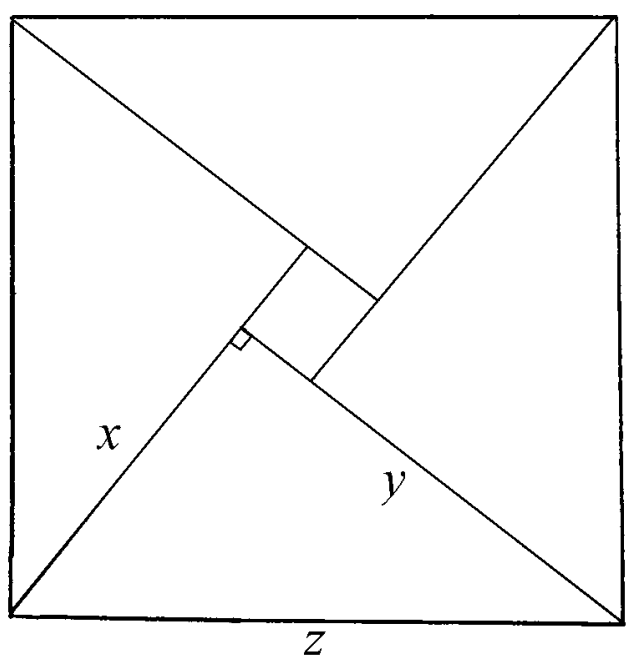

The area of the large square is $z^{2}$, that of the small square is $(y-x)^{2}$, and the area of each triangle is $\frac{1}{2} x y$. So $z^{2}=(y-x)^{2}+4\left(\frac{1}{2} x y\right)=x^{2}+y^{2}$. After 
reflecting on the diagram and accompanying explanation, it is supposed to become obvious that Pythagoras' Theorem is true.

Frege begins the Grundlagen with the remark that '[i]n arithmetic, if only because many of its methods and concepts originated in India, it has been the tradition to reason less strictly than in geometry, which was in the main developed by the Greeks' (1950: §1). There is more than a little racial stereotyping and ignorance in this comment. A contrast can indeed be made between the concepts of proof in India and Greece. What we must remember, however, is that the contrast is not between two ways of doing mathematics, but rather between two theories of what ideal proof consists in. The actual practice of mathematicians, whether in the west or in India, is to produce informal proof-sketches with many 'obvious' steps missing. Such real proofs are a far cry from what Frege's logicism led him to imagine an ideal proof should be. If the Indian theory as to what mathematical demonstration consists in is 'less strict' than Frege's ideal, this does not show that they reasoned less strictly, but rather that they conceived of the aim of rationality differently. Rationality in mathematics has for its goal what one might call 'real understanding' of a result, and not simply a proof that the result has to be true. For one can follow the steps of a formal proof, and thereby realise that the result has to be true, without gaining thereby any 'real' understanding of what the result shows, how it is or should be applied, or where its significance lies. For that reason, a proper understanding of a result includes, in part, an understanding of how it relates to actual examples. On this point - that proof must and argument must make an essential appeal to paradigms, examples and exemplars the philosophers and mathematicians in India agree. ${ }^{7}$

\section{NOTES}

1 I restrict my attention to the philosophers of the analytical stream of Indian philosophical thought, the Nyāya-Vaiśeșika. The main innovations are due to Kaṇāda (c. AD 100), Praśastapāda (c. 530), Bhāsarvajña (c. 950), Śrīdhara (c. 990), Udayana (c. 1000), Śaṇkara Miśra (c. 1430) and Raghunātha (c. 1510).

2 VS 7.2.7 is apparently directed against the Sāmkhya theory that there is an identity between cause and effect. 7.2.8 is due to the doctrine that, while all numbers greater than one are non-eternal, the number one is eternal when it resides in eternal substances (the atoms), and only non-eternal in non-eternal substances. We can ignore this rather obscure doctrine. See Faddegon (1918: 200-1).

3 The point is made by Udayana (1956: 459).

4 See, in particular, the discussion of objectivity in Evans (1985: 261-2).

5 It is difficult to find the view ascribed here to him. All he seems to say on the matter is this (1977: 270): 'If it is said that there is no number apart from substances, because 
a difference is not grasped, then that is not right. For when a close arrangement of trees is seen from a distance, even though oneness etc. is not grasped, one can still grasp their nature. Thus too is explained the difference [of number] from colour etc. Although from a distance the colour is not grasped, there is still an awareness of the substance [ $=$ the forest?]'.

6 Praśastapāda states (1977: 270) that, after one, the numerical qualities run from two to a large but finite number parārdha. The number parārdha is mentioned in many texts as the highest decimal place name. The precise value of parārdha varies: in the Taittirīya Samhitā (4.40.11.4, 7.2.20.1) and the Maitrāyani Samhitā (2.8.14), it is given as $10^{12}$, while the Kăthaka Samhitā records both $10^{12}(17.10)$ and $10^{13}$ (39.6). Among the mathematicians, it is always $10^{17}$. There are names for higher decimal powers in Buddhist and Jaina texts (Abhidharmakośa 3.93-94 names powers up to $10^{59}$ ). Only the Nyāya-Vaiśeșika take parārdha to be the highest number, and not merely the highest named place value. There is no room for the idea of a maximal finite number if one thinks of the number series as generated by recursive application of the successor function, but among the NyāyaVaiśesika authors, only Bhāsarvajña attempts so to construct the number series. Within a conception of numbers as qualities of substances, indeed, it seems that there has to be a largest number, if the number of things in the cosmos is finite.

7 For more on the role of examples in philosophical proof procedures and Indian problemsolving heuristics, see Ganeri (2001).

\section{REFERENCES}

Bhaduri, S.: 1947, Studies in Nyāya-Vaiśeșika Metaphysics, Bhandarkar Oriental Research Institute, Poona.

Bhāsarvajña: 1968, Nyāyabhūṣaṇa. Edited by Svami Yogindrananda, Saddarsan Prakasan Pratisthanam, Varanasi.

Dvivedi, Sudhakara: 1933, Lives of Hindu Astronomers (Ganaka-tarañgin̄ī), Benares.

Faddegon, B.: 1918, The Vaisessika System, Described with the Help of the Oldest Texts, Johannes Müller, Amsterdam.

Frege, G.: 1950, The Foundations of Arithmetic, translated by J. L. Austin. Blackwell, Oxford.

Gadādhara Bhațācārya: 1927, Śaktivāda, with Kṛ̣ṇa Bhaț̣a’s Mañjūṣa, Mādhava Bhațāāāya's Vivṛtti and Sāhitya Darśanācārya's Vinodini. Edited by G. D. Sastri. Kashi Sanskrit Series no.57, Benares.

Ganeri, J.: 1996, 'Numbers as Properties of Objects: Frege and the Nyāya', Studies in Humanities and Social Sciences, Vol. 3: Epistemology, Logic and Ontology after Matilal, Indian Institute of Advanced Studies, Shimla 3.2: 111-121.

Ganeri, J.: 1999, Semantic Powers: Meaning and the Means of Knowing in Classical Indian Philosophy, Clarendon Press, Oxford.

Ganeri, J.: 2001, Philosophy in Classical India, Routledge, London.

Gautama: 1985, Nyāyasūtra, with Vātsyāyana's Bhāsya, Uddyotakara's Vārttika, Vācaspati Miśra's Tātparyațīkā and Viśvanātha's Vṛtti. Edited by T. Nyāyatarkatīrtha and A. Tarkatīrtha. Calcutta: Calcutta Sanskrit Series nos. 18-19. Second Edition, Munshriram Manoharlal, Delhi.

Guha, D. C.: 1979, Navya-nyāya System of Logic, Second Edn, Motilal Banarsidass, Delhi. Herzberger, H. and R. Herzberger, 1981, 'Bhartrhari's Paradox', Journal of Indian Philosophy 9, 3-32. 
Ingalls, D. H. H.: 1951, Materials for the Study of Navya-Nyāya Logic, Harvard University Press, Cambridge, MA.

Kanāda: 1961, Vaiśesikasūtra of Kanāda, with the Commentary of Candrānanda, critically edited by Muni Sri Jambuvijaya, Oriental Institute, Gaekwad's Oriental Series 136, Baroda.

Kan̄āda: 1911, The Vaiśeșika Sūtras of Kañāda, with the Commentary of Śankara Miśra, translated by Nandalal Sinha, The Panini Office, Bhuvaneswari Asrama, Allahabad, pp. 233-244.

Matilal, B. K.: 1975, 'On the Navya-Nyāya Logic of Property and Location', in Proceedings of the 1975 International Symposium of Multiple-valued Logic, Indiana University, Bloomington, pp. 450-461

Matilal, B. K.: 1985, 'On the Theory of Number and Paryāpti in Navya-Nyāya', Journal of the Asiatic Society of Bengal 27, 13-21.

Matilal, B. K.: 1986, Perception: An Essay on Classical Indian Theories of Knowledge, Clarendon Press, Oxford.

Matilal, B. K.: 1989, 'Moral Dilemmas: Insights from Indian Epics', in B. K. Matilal (ed.), Moral Dilemas in the Mahābhārata, Indian Institute of Advanced Study, Shimla, pp. $1-19$.

Mohanty, J. N.: 1992, Reason and Tradition in Indian Thought. An Essay on the Nature of Indian Philosophical Thinking, Clarendon Press, Oxford.

Perrett, R.: 1985, 'A Note on the Navya-Nyāya Account of Number', Journal of Indian Philosophy 13, 227-234.

Potter, Karl: 1977, The Tradition of Nyāya-Vaiśesika up to Gañgeśa, Encyclopedia of Indian Philosophies, Vol. II, Motilal Banarsidass, Delhi.

Potter, Karl and Sibajiban Bhattacharyya: 1993, Indian Philosophical Analysis: NyāyaVaiśeșika from Gangeśa to Raghunātha Śiromani, Encyclopedia of Indian Philosophies, Vol. VI, Motilal Banarsidass, Delhi.

Raghunātha: 1957, The Padārthatattvanirūpanam of Raghunātha Siromani, edited and translated by Karl H. Potter, Harvard University Press, Harvard Yenching Institute Studies, Vol. 17, Cambridge, MA, pp. 86-87.

Raghunātha. Avacchedakatvanirukti with Jagadīśa's Jāgadīsín, Dharmananda Mahabhaga (ed.), Kashi Sanskrit Series 203, Varanasi.

Raja, K. K.: 1963, Indian Theories of Meaning, The Adyar Library, Madras.

Ramaiah, C.: 1976-7, 'Nyāya-Vaiśeșika Theory of Numbers (Sānkhyā)', Indian Philosophical Quarterly 4, 129-134.

Sainsbury, M.: 1979, Russell, Routledge \& Kegan Paul, London.

Sainsbury, M.: 1991, Logical Forms, Blackwell, Oxford.

Sainsbury, M.: 1995, Paradoxes, Second Edition, Cambridge University Press, Cambridge.

Śankara Miśra: 1923, Vaiśesikadarśana, with Praśastapāda's Padārthadarmasamgraha and Śankkara Miśra's Upaskāra, Dundhiraja Sastri (ed.), Chaukhamba Sanskrit Series Office, Kashi Sanskrit Series 3, Varanasi, pp. 173-180.

Sen, S. N.: 1995, 'History of Science in Relation to Philosophy and Culture in Indian Civilization', in D. P. Chattopadhyaya and R. Kumar (eds), Science, Philosophy and Culture in Historical Perspective, PHICPC Monograph 1, Munshiram Manoharlal, Delhi.

Shaw, J. L.: 1982, 'Number: From the Nyāya to Frege-Russell', Studia Logica 41, 283 291.

Shukla, K. S.: 1959, The Pātiganita of Śrīdharācārya with an Ancient Sanskrit Commentary, Kripa Shankar Shukia (ed.), Lucknow University Department of Mathematics and Astronomy, Lucknow. 
Śrīdhara: 1977, Praśastapādabhāsya with the Commentary Nyāyakandalī by Śrīdhara Bhatta, edited with Hindi translation, by Durgadhara Jha, Sampurnanand Sanskrit Vishvavidyalaya, Ganganatha Jha Granthamala, Varanasi, Vol. 1, pp. 267-214.

Śrīdhara: 1907-8, Padārthadharmasamgraha with Śrīdhara's Nvāyakandalī, translated by Ganganatha Jha, The Pandit, n.s. Vols. 29-30, pp. 241-284.

Srinivas, M. D.: 1992, 'The Methodology of Indian Mathematics and its Contemporary Relevance', in G. Kuppuram and K. Kumudamani (eds), History of Science and Technology in India, Vol. II, pp. 29-86.

Udayana: 1956, Kiranāvalī, with Vardhamāna's Prakāśa and Vādīndra's Rasasāra, Narendra Chandra Vedantatirtha (ed.), The Asiatic Society, Bibliotheca Indica no. 200, fasc. 4, Calcutta, pp. 441-462.

Divinity School

University of Chicago

1025 East 8th Street

Chicago IL 60637

U.S.A. 
